\title{
A TAR-TÓ 2000 SZÖVETKEZET MŰKÖDÉSÉNEK ÉS FUNKCIÓINAK ÉRTÉKELÉSE A TAGOK VÉLEMÉNYÉNEK TÜKRÉBEN
}

\author{
Kovács Helga - Kis Krisztián
}

\begin{abstract}
Absztrakt: Tanulmányunkban a szövetkezetek kettős szerepéből kiindulva vizsgáljuk a TAR-TÓ 2000 Szövetkezet müködésének a tagok gazdasági helyzetére gyakorolt hatását, illetve fontos célként jelenik meg a közösségi és humanisztikus célok érvényesülésének bemutatása és értékelése is. Vizsgálatainkhoz szükséges primer adatokat a tagokkal készített kérdöíves kutatás szolgáltatta. Elemzésünkböl kiderül, hogy a szövetkezet által ellátott különböző szerepkörök nagymértékben elömozdítják a tagok gazdasági teljesítményét. A csoportkohézió és a bizalom vizsgálata arra enged következtetni, hogy az anyagi előnyökön túl a szövetkezet müködése a közösségiség szempontjából is pozitívan értékelhető. Mindez visszahat a szövetkezet és a tagok müködésére, tovább fokozva a gazdasági teljesítményt, ami jó alapot adhat a bizalom és a csoportkohézió további erősödéséhez, a társadalmi célok eléréséhez; összességében a szövetkezet eredményes, hatékony és fenntartható müködéséhez.

Abstract: In our study, based on the dual role of co-operatives, we examined the impact of the operation of TAR-Tó 2000 Co-operative on the economic situation of the members, we also presented and evaluated the emergence of community and humanistic goals. The primary data required for our investigations was provided by the questionnaire research conducted among the members of the cooperative. Our analysis reveals that the various roles provided by the co-operative greatly promote the economic performance of the members. The examination of group cohesion and trust suggests that beyond the material benefits, the operation of the co-operative can be assessed positively from a community point of view. All of this can react to the operation of the co-operative and the members, further enhancing economic performance, which can provide a good basis for further strengthening of trust and group cohesion and to achieve social goals, and thus for the effective, efficient and sustainable operation of the co-operative.
\end{abstract}

Kulcsszavak: szövetkezet, kettös szerep, közösség, eredményesség, hatékonyság, bizalom

Keywords: co-operative, dual role, community, effectiveness, efficiency, trust

\section{Bevezetés, témafelvetés}

A szövetkezetek ma minden országban és minden szektorban jelen vannak, ezért nagyon fontos szerepet játszhatnak a jövő társadalmi és gazdasági folyamataiban, illetve azok formálásban. Kettős szerepük révén a szövetkezetek megélhetést biztosítanak tagjaik számára, ami pedig hozzájárul a társadalmi és kulturális célok felé való elmozduláshoz. Továbbá hozzájárulnak az információ és szakmai ismeretek elterjedéséhez, mely innovációra ösztönözheti a gazdálkodókat, ami segít alkalmazkodni a változó piaci viszonyokhoz. A szövetkezetek elősegítik a termelők nagyobb alkuerejét a piacon hozzájárulva a tranzakciós költségek csökkentéséhez. Esettanulmányunkban a TAR-TÓ 2000 Szövetkezet müködését és annak sajátosságait vizsgáljuk gazdasági és társadalmi szempontból is, kiemelve a bizalom, az innováció és a csoportkohézió szerepét. 


\section{A szövetkezetek fejlődésének története}

Európát nevezhetjük a szövetkezeti mozgalom bölcsőjének, hiszen innen terjedtek el a szövetkezetek más iparosodó országokba, felvéve a harcot a szegénységgel szemben (Hoyt, 1989 idézi Ortmann-King, 2007). Azokon a helyeken sikerült a szövetkezeti mozgalmaknak eredményeket felmutatnia, ahol a szövetkezésben résztvevök között valamiféle összetartástudat létezett, sikerült megfogalmazni közös célokat és törekvéseket, ugyanakkor rendelkeztek elegendő szellemi és anyagi eröforrással kezdeményezésük megvalósításához.

1844-ben, az észak-angliai Rochdale városában található gyapotmalmokban dolgozó 28 kézmüves csoport létrehozta az első modern kooperatív vállalkozást, a Rochdale Equitable Pioneers Society-t, mely a modern szövetkezések prototípusának tekinthető. Továbbá elmondható, hogy az egyik legnagyobb elörelépést az általuk megfogalmazott szövetkezetek müködésének alapelvei jelentették. Egy másik fontos dolog a szövetkezeteket szolgáló hitel- vagy pénzintézetek kialakítása volt, mely a kisebb. vállalkozóknak, különösen az iparosoknak és földműveseknek segített megtalálni a számukra szükséges hitelforrást, amire nem volt lehetőségük az akkori bankrendszerben, ugyanis azok a nagyobb arányú hitelezésekre voltak berendezkedve (Hunyadi, 2007; IngalsbeGroves, 1989 idézi Ortmann-King, 2007). Az első megtakarítási- vagy hitelszövetkezetet 1864-ben alapította Friedrich Wilhelm Raiffeisen Németországban. A szövetkezetek fejlödését számos dolog befolyásolta, melyet három nagy csoportba sorolhatunk: gazdasági okok (kormányzati gazdaságpolitika), gazdálkodó szervezetek (vezetés minősége, motiváció) és a közrend (kormány érdek, jogalkotási kezdeményezések) (Ingalsbe-Groves, 1989 idézi Ortmann-King, 2007).

A Szövetkezetek Nemzetközi Szövetségét (International Co-operative Alliance - ICA) 1895-ben alapították Londonban, Argentína, Ausztrália, Belgium, Anglia, Dánia, Franciaország, Németország, Hollandia, India, Olaszország, Svájc, Szerbia és az USA részvételével. A Szövetség célja az volt, hogy információkat szolgáltassanak, meghatározzák és megvédjék a szövetkezeti elveket és fejlesszék a nemzetközi kereskedelmet (ICA, é.n.).

\section{A szövetkezetek rövid története Magyarországon}

A szövetkezeti viszonyok Magyarországon a történelem alakulása miatt a többi országtól eltérő fejlődési pályát írtak le. Elsősorban az uzsora elleni harc jegyében a kisvárosok polgárainak hitelegyletei alakultak meg a 19. század közepén, mint a szövetkezeti mozgalom elöfutárai. Az Országos Központi Hitelszövetkezet 1898ban alakult, a hitelszövetkezeti mozgalom irányítójaként. Szintén ekkor alakult meg a Hangya Termelö, Értékesítő, Fogyasztási Szövetkezet, Károlyi Sándor a magyar szövetkezeti mozgalom vezéralakja vezetésével. A mezögazdasági termelésben és áruforgalom lebonyolításában azonban a szövetkezetek nem tudtak fontos szerepet betölteni, annak ellenére, hogy ök bonyolították az áruk belföldi gyüjtését, szétosztását, kivitelét, valamint az importáruk behozatalát (Viszket, 2013). 
1949-ig a Hangya volt a legjelentősebb fogyasztási szövetkezet, mely kormányzati nyomás hatására megszünt a hitel-, lakás-, diákszövetkezetek és azok központjaival együtt. 1949-ben létrehozták a Szövetkezetek Országos Szövetségét, a SZÖVOSZ-t. 1949-1950-töl kezdve a szövetkezetek lényegében állami begyúijtő és ellátó szervekké váltak. A termelöszövetkezeti szervezés kívülröl, közvetlenül a párt és az állami szervek akciójaként szerveződött. Legfontosabb jellemzőjük, hogy a tagok gazdaságai közös szövetkezeti üzemben egyesültek. A kilencvenes évek elején a rendszerváltás sem hozta meg a hozzá füzött reményeket, hiszen gazdasági szempontból nem alakultak ki önkéntes társulási formák. A megszünt szövetkezetek helyébe az alkalmazottakkal dolgozó tőkés vállalkozók léptek. A válság ellenére, mely az agráriumot teljesen áthatotta elindultak olyan, alulról építkezö szerveződések, amelyekröl elmondható, hogy a klasszikus szövetkezeti elvek mentén müködtek. Ma a szövetkezetek további terjedésének számos oka és gátja van, mint például a nem mindig pozitív szemlélet, az információ és együttmüködés előnyeire vonatkozó felismerés és anyagi források hiánya, valamint kismértekben a bizalmatlanság is szerepet játszik (Simon, 1999).

\section{A szövetkezetek múködésének jellemzői: alapelvek, alapértékek}

A szövetkezés lényegét és müködését a nemzetközileg is elfogadott alapelvek és alapértékek határozzák meg. Annak érdekében, hogy a szövetkezetek azonos értékrend mentén mủködjenek fogadták el az alapértékeket, az alapelvek pedig iránymutatást adnak az alapértékek gyakorlatba való átültetéséhez (Kis et al., 2016).

Szövetkezeti alapértékek: A szövetkezeti alapértékek olyan erkölcsi normák, amelyek egy egész közösség viszonyainak minőségét megalapozzák. A leginkább ismerté vált alapértékek a nyíltság, a becsületesség, a demokrácia, az egyenlőség, az igazságosság, a szolidaritás, a másokkal való törődés, az egyéni felelősség, illetve az önsegély. Az alapértékek (1. táblázat) rávilágítanak a szövetkezetek társadalomban vállalt szerepére és annak fontosságára (SZÖVKUT, é.n.).

Szövetkezeti alapelvek: 1844-ben a rochdale-i „derék úttörők” által alapított szövetkezet müködési szabályaiból leszürt alapelveket fogadták el elöször. Az itt elfogadott alapelvek alkalmasak voltak arra, hogy ezek alapján újabb szövetkezetek alakuljanak. Ezen alapelvek alapján fogalmazták meg a szövetkezetek fogalmát is, ami kezdetektöl figyelembe vette a szövetkezetek müködésének kettős, gazdasági és társadalmi szerepét. Ezek szorosan összefüggnek, hiszen ha nem eredményes egy adott szövetkezet gazdasági tevékenysége, az a társadalompolitikai célú tevékenysége kudarcát is maga után vonja. 1937-ben Párizsban megtartott kongresszuson a Szövetkezetek Nemzetközi Szövetsége tovább bővítette az alapelveket, majd ezeket 1968-ban felülvizsgálták a bécsi kongresszuson. Az itt meghatározott alapelvek lehetővé tették, hogy újabb hosszú perióduson keresztül egységes és sikeres legyen a szövetkezeti mozgalom. Figyelembe véve a világ társadalmi-gazdasági körülményeit szükség volt az alapelvek módosítására és kiegészítésére. Ezek hatására a Szövetkezetek Nemzetközi Szövetsége 1995-ben, Manchesterben meghatározta a ma is használt és elfogadott alapelveket (1. táblázat) (SZÖVKUT, é.n.). 
1. táblázat: A szövetkezetek múködésének alapelvei és alapértékei

\begin{tabular}{|l|l|}
\hline \multicolumn{1}{|c|}{ Alapértékek } & \multicolumn{1}{c|}{ Alapelvek } \\
\hline Nyíltság & Önkéntes és nyitott tagság \\
\hline Becsületesség & Demokratikus tagi ellenörzés \\
\hline Demokrácia & A tagok gazdasági részvétele \\
\hline Egyenlöség & Autonómia és függetlenség \\
\hline Igazságosság & Oktatás, képzés és tájékoztatás \\
\hline Szolidaritás & Szövetkezetek közötti együttmüködés \\
\hline Másokkal való törödés & Felelösség a közösségért \\
\hline Egyéni felelösség & \multicolumn{1}{|c}{} \\
\cline { 1 - 2 } Önsegély &
\end{tabular}

Forrás: SZÖVKUT (é.n.)

\section{A szövetkezetek kettős szerepe}

A szövetkezetek különböznek más vállalkozási formáktól, hiszen céljuk nem a profit maximalizálása, hanem hogy tagjai számára előnyöket nyújtson az áruk és szolgáltatások piacán (Jussila et al., 2008 és Jussila, 2007 idézi Puusa et al., 2013). Tágabb értelemben a szövetkezetek célja, hogy elömozdítsák a gazdasági jólétet és fenntartsanak egy jobb életszínvonalat tagjaik számára. Ezek alapján beszélhetünk a szövetkezetek kettős szerepéről vagy kettős céljáról, mely egyrészt gazdasági tevékenység, másrészt a szociális problémák megoldására keres választ, hiszen a nyereségre való törekvés mellett figyelembe veszi az emberi tényezőket is (Petheő et al., 2010; Puusa et al., 2013).

A szövetkezetek kettős szerepére utal a 2012-es évi Élelmezési Világnap alkalmából megjelent FAO (2012a) kiadványban szereplö meghatározás is, mely szerint a szövetkezet egy olyan társadalmi vállalkozás, melynek két célja van: tagjainak igényeit elégíti ki, valamint hasznot és fentarthatóságot eredményez. Más FAO (2012b) kiadvány meghatározása szerint a szövetkezet emberek autonóm társulását jelenti, akik önként egyesülnek, azért, hogy gazdasági, társadalmi és kulturális igényeiket és törekvéseiket véghezvigyék egy közös tulajdonú vállalkozás kereti között. Tehát, egy olyan üzleti vállalkozásról van szó, mely egyensúlyt teremt a tagjai igényeinek kielégítése, valamint a haszon és a fenntarthatóság között. Szóval a szövetkezetek elönyöket biztosítanak a tagjaik számára, miközben pozitív hatással vannak az egész társadalomra (Puusa et al., 2013).

A szövetkezetek gazdaságban és társadalomban betöltött szerepét sokszor nehéz elválasztani egymástól. Többek között segítenek a természeti erőforrásokhoz, az információhoz, a kommunikációhoz, a piacokhoz, a technológiákhoz és a képzéshez való hozzáférésben. Központi szerepet játszanak a kistermelök szaktudásának fejlesztésében, ellátva öket szakmai ismeretekkel, ezzel elösegítve a piaci viszonyokhoz való alkalmazkodásukat. Növelik a termelök hozzáférését a piacokhoz és a termelési eszközökhöz, miközben csökkentetik a magas tranzakciós költségeket. Néhány szövetkezet lehetővé teszi a gazdálkodók számára, hogy képesek legyenek termelési rendszereik elemzésére, problémáik azonosítására, a lehetséges megoldások tesztelésére és végül a gazdálkodási rendszerükhöz leginkább megfelelö gyakorlatok és technológiák alkalmazására (FAO, 2012b). 
A gazdasági és társadalmi fejlődés alappilléreként fontos szerepet játszanak a munkahelyteremtésben, a humán erőforrás fejlesztésben, a társadalmai kirekesztés visszaszorításában, az erőforrások, valamint a jövő generációjának mobilizálásában. Lehetőséget teremtenek a munka, valamint az abból származó jövedelem igazságosabb elosztásában, hozzájárulva a szegénység enyhítéséhez és az éhezés leküzdéséhez (Dorgai et al., 2005; FAO, 2012b).

\section{A szövetkezetekkel kapcsolatos közgazdaságtani elméletek}

A szövetkezetekkel összefüggésben három fontos közgazdaságtani elméletet emelhetünk ki, ez a tulajdonjogok elmélete, a tranzakciós költségek elmélete és az 'ügynök/megbízó elmélet, melyek rávilágítanak az együttműködésekből fakadó problémákra és elönyökre, valamint a szövetkezetek müködésének sajátosságaira.

Tulajdonjog elmélete (Property rights theory): A tulajdonjogok elméletének középpontjában a tulajdonjog intézménye áll, mely meghatározza azt, hogy a tulajdonos, azon eröforrások felett, amire a jogosultsága vonatkozik, hogyan és milyen módon rendelkezhet. Három alapvetése van, mely szerint az egyének saját hasznuk maximalizálására törekszenek, meghatározza, hogy ki milyen erőforrást, hogyan, mikor, milyen formában és mértékben használhat legitim módon, továbbá, azt mondja, hogy a tulajdonjogok átruházása és érvényesítése költséget okoz, amit tranzakciós költségeknek nevezünk. Elkülönítjük a közösségi és a magántulajdont, hiszen a közösségi tulajdont nem lehet úgy használni, hogy másokat kizárjunk a használatból, valamint ebben az esetben a tulajdonjogok nem ruházhatók át. Azoknak az eröforrásoknak a használata nincs korlátozva, amelyek közösségi tulajdonban vannak, így ezeket sokkal intenzívebben használják, mintha magántulajdonban lennének (Lukács, 2005).

Ha a szövetkezeteket a tulajdonjog szempontjából vizsgáljuk, több alapvetö jellegzetességet is megfigyelhetünk. A szövetkezetek esetében a tulajdonosok egyben a termelők is, tehát tulajdonjogi szempontból is egy speciális szervezetről van szó, ahol a tagok kötelesek gazdasági tevékenységet végezni. Azok a jogok, amelyek a haszonhoz, irányításhoz és ellenőrzéshez füződnek ugyanannak a csoportnak a kezében vannak. Csak a tagi tulajdonos gyakorolhatja a tulajdonjogokat, a profitot ebben az esetben a szövetkezettel való uizleti tevékenység arányában osztják vissza, továbbá a tulajdonosi jogokat nem lehet átadni, nem lehet őket úgy kezelni, mint a tőzsdén a részvénytársaság részvényeit. A határozatlanul definiált tulajdonjogok megkérdőjelezhetik a szövetkezeti hatékonyságot, valamint korlátozhatják a befektetői hajlandóságot (Kispál-Vitai, 2006).

Tranzakciós költségek elmélete (Transaction cost economics): Minden gazdasági esemény egy tranzakció, melyeknek a költsége pontosan meghatározható a tranzakciós költségek elmélete szerint. A költségek racionalizálása és csökkentése egyre inkább fontossá válik az egyre élesedő versenyben (Oláh et al., 2016). A tranzakciós költségek vizsgálatának az oka a vállalatok növekedése volt, hiszen ahogy a vállalatok fejlödtek, üzleti kapcsolataik kiteljesedtek egyre több tranzakciót hajtottak végre. Kérdés tehát, hogy a tranzakciós költségek miként csökkenthetök, 
annak érdekében, hogy a vállalatok tovább tudják növelni részesedésüket a piacon (Lukács, 2005).

A megoldás a szövetkezésben rejlik. A szövetkezetek azáltal, hogy a kereslettel kapcsolatos információkat jobban áramoltatják, valamint a fogyasztókat közelebb hozzák a termelőkhöz, mérséklik a technológiai és piaci bizonytalanságot így képesek csökkenteni a tranzakciós költségeket, növelve a tagok jövedelmét (Szabó, 2013). Továbbá képesek csökkenteni a tranzakciós költségeket az információs rendszerek fejlesztése révén, piaci intézmények létrehozásával, hiszen egy nagybani piac, vagy tőzsde létrehozása hatalmas költség, viszont egy intézmény létrehozásával sokkal kevesebb egy szereplöre leosztva (Fogarassy-Villányi, 2004). A tranzakciós költségek elméletében alapvető kritikus jellemző a tranzakciók bizonytalansága, gyakorisága és specifikussága. A bizonytalanság a vállalatok vertikális integrációjának lehet oka, míg a gyakoriság a vertikális integráció hatékonyságának lehet feltétele, hiszen ha egy terméket vagy szolgáltatást ritkán vásárolnak nincs értelme az integrációnak. A tranzakciók specifikussága nagy hatással van a két tranzakciós fél közötti viszony meghatározására. Vonatkozhat az eszközök fizikai tulajdonságára, az emberi erőforrások jellegzetességeire vagy bizonyos fogyasztók kiszolgálására (Williamson, 1985 idézi Kispál-Vitai, 2006). Összeségében versenyelönyt jelent a mezőgazdasági termelöknek, hiszen csökken a piacra jutás költsége és ezáltal is nő a termelés jövedelmezösége (Villányi-Vasa, 2008).

$\ddot{U}$ gynök/megbízó elmélet (Agency theory): A tranzakciós költségek elméletének továbbfejlesztett változata a megbízási elmélet, ahol a tranzakciókról a megbízásra, vagyis a szerződésre helyezi a hangsúlyt. A tranzakció az ügynök és a megbízó között jön létre, melyet szerződés rögzít, mindkét fél jogaival és kötelezettségeivel együtt. Az uigynöktől azt várják el, hogy bizonyos feladatokat jobban hajtson végre, mint megbízója (Lukács, 2005). A probléma lényege tulajdonképpen, hogy a menedzserek, ügynökök jól képviselik-e a tulajdonosok, megbízók érdekeit, alapja pedig az az információs aszimmetria, mely abból adódik, hogy a tulajdonosoknak nincsenek pontos információi a vállalat tartalékairól és lehetséges teljesítményéröl, míg a vezetőknek vannak (Chikán, 1992).

Továbbá az ügynök szélesebb körü információkkal rendelkezik arról, hogy mennyire felkészült, vagy elhívatott a szerződésben rögzített feladattal szemben. A megbízó nem, vagy csak nagyon költséges módon tudja ellenörizni az ügynök teljesítményét. Ez a tény teszi lehetővé azt, hogy az ügynök teljesítménye csökkenhet, hiszen kihasználja a közte és a megbízó közötti információs aszimmetriát és visszaél a hatalmával, tehát úgy fog cselekedni, ahogy neki a legjobb és nem úgy, ahogy a megbízójának (Kispál-Vitai, 2013; Lukács, 2005).

A szövetkezetek esetében kezdetben a tulajdonlás és az irányítás nem válik el egymástól, hiszen a tagok, tulajdonosok az irányítók. Ha a szövetkezet növekszik és a tevékenysége komplexé válik, akkor lesz szükség menedzser alkalmazására, aki lehet tag vagy kívülálló, és ebben az esetben azonnal megjelennek az ügynökelméletben kifejtett problémák (Kispál-Vitai, 2013). 


\section{Anyag és módszer}

Kutatásunk módszerének a kérdőíves felmérést választottuk. Az általunk vizsgált TAR-TÓ 2000 Értékesítő, Beszerző és Feldolgozó Szövetkezet jelenleg hatvan taggal müködik, Sándorfalva székhellyel. A vizsgálat során 39 gazdálkodót vettünk figyelembe, hiszen öt tag gazdasági társaságként és magánszemélyként is szerepel, emellett a családi gazdaságok több családtagja is tagja a szövetkeznek, mint például férj és feleség, apa és fia. A jelenleg csatlakozott fiatal gazdák, illetve azok a tagok, akik még nem értékesítettek a Szövetkezeten keresztül, nem kerültek megkérdezésre. 39 tag közül 35-en töltötték ki a kérdőívet, személyes találkozás során és e-mailen keresztül. 2017. március 24-én kezdődött el a kérdöívek kitöltetése és egészen április végig tartott. A személyes kitöltés a fogadóórák keretei között zajlott, minden kedden és pénteken délután kettőtől ötig. A gazdák egy részével a távolság és személyes okok miatt nem jöhetett létre a személyes találkozás, így nekik e-mailben juttattuk el a kérdöíveket, majd ezt követően telefonon is megkerestük őket.

\section{Kutatási eredmények és értékelésük}

8.1. A TAR-TÓ 2000. Értékesítö, Beszerző és Feldolgozó Szövetkezet rövid története

A TAR-TÓ 2000 Szövetkezet 1999. december 20-án alakult meg 15 alapító taggal. Megalakulásakor a Szövetkezet célja a sertések biztonságosabb értékesítése volt, a közös beszerzés lehetősége még nem merült fel. Ekkor körülbelül $950 \mathrm{db}$ sertést értékesített évente a szövetkezet. Az elsö elnöke Gergulics István volt, majd 2002ben választották meg Vas Csabát, aki azóta is betölti ezt a pozíciót. Innentől kezdve nem csak közös értékesítéssel, hanem közös beszerzéssel is elkezdett foglalkozni a Szövetkezet. 2007-től alkalmazott először közös állatorvost, aki ettől az évtől 2012ig szaktanácsadóként is müködött. 2008. január 21. napján már 42 taggal nyerte el az állami elismerést, 'mint termelői csoport. A nagyobb beruházások 2013-tól kezdődtek, mely során egy telepet vásárolt a Szövetkezet Sándorfalván, takarmánykeverővel együtt, mely lehetővé tette a tagok számára szemestakarmányuk raktározását, darálását és keverését.

Ma az üzleti partnerek tekintetében egy vágóhíddal áll kapcsolatban a Szövetkezet a Hungary Meet Kft.-vel, és három premix beszállító céggel, a győri AgroFeed Kft.-vel, a Mecsek Pig Kft.-vel, valamint a budapesti székhelyü Nutrifeed Kft.-vel. A partnerek egy része folyamatosan változik, de vannak, akikkel évek óta kapcsolatban állnak. A beszerzés nem, viszont az értékesítés kötelező a szövetkezeten keresztül. 2016-ban 32081 db sertést értékesített a Szövetkezet 57 tagja.

8.2. A szövetkezet tagjaira és a gazdaságukra vonatkozó alapadatok

A szövetkezet tagjaira és a gazdaságaikra vonatkozó alapadatok kapcsán a megkérdezett szövetkezeti tagok közül 6 nő és 29 férfi gazdálkodó van, akik többsége középkorú, azaz 40 és 55 év közötti. A legtöbb tag Sándorfalván és a környező településeken él, mint például Ópusztaszeren, Dócon, Kisteleken, 
Szegeden, Hódmezővásárhelyen, Szatymazon és Domaszéken. Emellett vannak olyan tagjai is a szövetkezetnek, akik Békés megyéböl és Bács-Kiskun megyéböl származnak.

A tagok iskolai végzettségét tekintve körülbelül 45\%-uk rendelkezik érettségivel, $11 \%$-uk egyetemi vagy föiskolai végzettséggel, míg a többiek alapfokú végzettséggel, illetve szakképesítéssel. A felmérésböl az is kiderül, hogy a gazdálkodók 25\%-a nem rendelkezik semmilyen mezőgazdasági végzettséggel, csak saját és felmenőik tapasztalaikra támaszkodnak, míg a többiek aranykalászos gazda, mezőgazdasági technikus, növénytermesztő, gépész, méhész, hentes, agrármérnök, és erdésztechnikus végzettséget szereztek.

A tagok körülbelül fele-fele arányban végzik fö- és kiegészítő tevékenységként a sertéstartást, sertéshízlalást. A szövetkezet tagjai közül 10-en családi gazdaság kereti között, 11-en egyéni vállalkozóként, 7-en Kft. formájában 7-en őstermelőként gazdálkodnak, de vannak olyan tagok is, akik egyéni vállalkozóként és családi vállalkozásként müködnek, mégis rendelkeznek őstermelői igazolvánnyal. A vállalkozás formáját a gazdaság mérete és az abból származó jövedelem, ami leginkább meghatározza.

A gazdálkodásból származó jövedelem az elmúlt öt évben 16 gazda véleménye szerint összességében átlagos volt, 17 gazda szerint összességében alacsony volt és csupán ketten vallották azt, hogy nem származott veszteségük, de jövedelmük sem a gazdálkodásból. A szövetkezeti tagság feltétele, hogy a belépni kívánó tag kötelezettséget vállal arra, hogy saját gazdaságából évente legalább $100 \mathrm{db}$ hízósertést értékesít a szövetkezeten keresztül, így minden tag foglalkozik hízósertés nevelésével. A tagok közül heten kocatartással és malacneveléssel is foglalkoznak, biztosítva a saját hízóalapanyagukat, valamint a többi tagét is igény szerint.

\subsection{A szövetkezet nyújtotta gazdasági elönyök értékelése}

A szövetkezetek gazdasági elönyökhöz juttatják a gazdákat az együttmüködések által, melynek legfontosabb célja a hatékonyság javítása, ami által pedig magasabb jövedelem realizálása, ami hozzásegítheti a tagokat az életszínvonaluk javításához, ezáltal növelve a társadalmi és kulturális célok felé való elmozdulást. 


\section{2. táblázat: A szövetkezet hozzájárulása az egyes tényezőkhöz a tagok} véleményének tükrében

\begin{tabular}{|c|c|c|c|c|c|}
\hline Megnevezés & $\begin{array}{c}\text { Egyáltalán } \\
\text { nem }\end{array}$ & Kismértékben & Közepesen & Nagymértékben & Alapvetően \\
\hline Könnyebb értékesítés & $0 \%$ & $0 \%$ & $0 \%$ & $20 \%$ & $80 \%$ \\
\hline Magasabb piaci árak & $0 \%$ & $0 \%$ & $8 \%$ & $26 \%$ & $66 \%$ \\
\hline Kiszámíthatóbb termelésszervezés & $0 \%$ & $3 \%$ & $12 \%$ & $31 \%$ & $54 \%$ \\
\hline Minőségjavulás & $0 \%$ & $12 \%$ & $14 \%$ & $31 \%$ & $43 \%$ \\
\hline Naturális hatékonyság javulása & $3 \%$ & $6 \%$ & $20 \%$ & $31 \%$ & $40 \%$ \\
\hline $\begin{array}{l}\text { Az értékesítés árbevételének, } \\
\text { biztosabb, biztonságosabb realizálása }\end{array}$ & $0 \%$ & $0 \%$ & $6 \%$ & $46 \%$ & $48 \%$ \\
\hline $\begin{array}{l}\text { Állategészségügyi } \quad \text { kockázatok } \\
\text { csökkenése; állategészségügyi helyzet } \\
\text { javulása }\end{array}$ & $0 \%$ & $3 \%$ & $23 \%$ & $37 \%$ & $37 \%$ \\
\hline $\begin{array}{l}\text { Támogatásokhoz való könnyebb } \\
\text { hozzáférés }\end{array}$ & $3 \%$ & $3 \%$ & $12 \%$ & $31 \%$ & $51 \%$ \\
\hline Alacsonyabb beszerzési árak & $9 \%$ & $3 \%$ & $14 \%$ & $14 \%$ & $60 \%$ \\
\hline $\begin{array}{l}\text { Információhoz, tudáshoz való } \\
\text { könnyebb hozzájutás }\end{array}$ & $0 \%$ & $0 \%$ & $11 \%$ & $26 \%$ & $63 \%$ \\
\hline Jövedelmezöségi helyzet javulása & $0 \%$ & $3 \%$ & $17 \%$ & $43 \%$ & $37 \%$ \\
\hline Pénzügyi, likviditási helyzet javulása & $0 \%$ & $3 \%$ & $11 \%$ & $46 \%$ & $40 \%$ \\
\hline
\end{tabular}

Forrás: Kérdőíves felmérés alapján saját szerkesztés

Felmérésünkben megkérdeztük a tagokat, hogy véleményük szerint mennyiben járul hozzá a szövetkezet az 2. táblázatban foglalt tényezőkhöz. A tagok véleménye szerint a szövetkezet a könnyebb értékesítéshez, az információhoz, tudáshoz való könnyebb hozzájutáshoz, a magasabb piaci árak, valamint az alacsonyabb beszerzési árak eléréshez járul hozzá a leginkább. A legkevésbé tudja befolyásolni és tud hozzájárulni az állategészségügyi kockázatok csökkentéséhez és az állategészségügyi helyzet javulásához, valamint a jövedelmezőségi helyzet javításához.

A TAR-TÓ 2000 Szövetkezet jelenleg egy vágóhíddal áll kapcsolatban, a Kiskunfélegyházi Hungary Meat Kft.-vel, ahova az elmúlt évben 32081 db sertést értékesített. A Szövetkezet szervezi meg a sertésszállítások időpontját, és a módját is, ami által csökkenek a tranzakciós költségek és hozzájárul a kiszámíthatóbb termelésszervezéshez is. A sertéseladási árakat a német és a holland átlagárak alapján határozza meg a szövetkezet menedzsmentje, a tagok beleegyezésével. Lehetősége nyílik a tagoknak a közös hízóalapanyag, adalékanyag és takarmánybeszerzésre, így ezekhez olcsóbban jutnak hozzá a gazdák. A közös beszerzés nem, de a közös értékesítés kötelezö, ami azt jelenti, hogy évente legalább 100 sertést a szövetkezeten keresztül kell, hogy értékesítsenek a tagok.

A szövetkezeti tagok 17\%-a mondta azt, hogy a tapasztalatcsere, tájékozódás és az új ismeretek megszerzése miatt is jár a fogadóórákra az ügyintézés mellett, ami alátámasztja a szövetkezet szerepét az információ és tudásáramlásban.

A felmérés során az is kiderült, hogy a gazdák $34 \%$-a szerint a szövetkezeti tagság tevékenysége eredményes végzéséhez teljes mértékben, a tagok $46 \%$-a szerint nagyon, és 20\%-a szerint közepes mértékben járul hozzá. Összeségében megállapíthatjuk, hogy a szövetkezet leginkább a közös értékesítésben játszik fontos szerepet a gazdák véleménye szerint, de emellett számos fontos tényező segítségével is hozzájárul a tagok eredményes müködéséhez. 


\subsection{A csoportkohézió értékelése}

A szövetkezeti tagság nem csak anyagi előnyöket nyújt a gazdálkodóknak, hanem egyben egy közösséghez való tartozás is jelent. A csoportkohézió az az erö, ami ezt a közösséget összefogja, összetartja. A 3. táblázat alapján látható, hogy a megkérdezett gazdák, hogyan ítélik meg a csoportkohéziót a szövetkezeten belül.

\section{3. táblázat: A csoportkohézió megítélése}

\begin{tabular}{|c|c|c|c|c|}
\hline \multicolumn{5}{|c|}{$\begin{array}{l}\text { Úgy érzem, hogy a szövetkezeti tagság nemesak anyagi előnyöket ad nekem, hanem } \\
\text { egyben egy közösséghez való tartozást is jelent. }\end{array}$} \\
\hline $\begin{array}{l}\text { Egyáltalán nem } \\
\text { értek egyet }\end{array}$ & $\begin{array}{l}\text { Inkább nem } \\
\text { értek egyet }\end{array}$ & $\begin{array}{l}\text { Közömbös } \\
\text { számomra }\end{array}$ & $\begin{array}{l}\text { Inkább } \\
\text { egyetértek }\end{array}$ & $\begin{array}{l}\text { Teljes mértékben } \\
\text { egyetértek }\end{array}$ \\
\hline $0 \%$ & $0 \%$ & $9 \%$ & $34 \%$ & $57 \%$ \\
\hline \multicolumn{5}{|c|}{ Büszkeséggel és elégedettséggel tölt el, hogy a szövetkezet tagja lehetek. } \\
\hline $\begin{array}{c}\text { Egyáltalán nem } \\
\text { értek egyet }\end{array}$ & $\begin{array}{c}\text { Inkább nem } \\
\text { értek egyet }\end{array}$ & $\begin{array}{l}\text { Közömbös } \\
\text { számomra }\end{array}$ & $\begin{array}{c}\text { Inkább } \\
\text { egyetértek } \\
\end{array}$ & $\begin{array}{c}\text { Teljes mértékben } \\
\text { egyetértek }\end{array}$ \\
\hline $0 \%$ & $0 \%$ & $11 \%$ & $20 \%$ & $69 \%$ \\
\hline \multicolumn{5}{|c|}{$\begin{array}{c}\begin{array}{c}\text { Elkötelezett vagyok a tagok közötti összefogás és az együttmúködés magasabb szintre } \\
\text { emelésében. }\end{array} \\
\end{array}$} \\
\hline $\begin{array}{c}\text { Egyáltalán nem } \\
\text { értek egyet }\end{array}$ & $\begin{array}{l}\text { Inkább nem } \\
\text { értek egyet }\end{array}$ & $\begin{array}{l}\text { Közömbös } \\
\text { számomra }\end{array}$ & $\begin{array}{c}\text { Inkább } \\
\text { egyetértek }\end{array}$ & $\begin{array}{l}\text { Teljes mértékben } \\
\text { egyetértek }\end{array}$ \\
\hline $0 \%$ & $0 \%$ & $8 \%$ & $26 \%$ & $66 \%$ \\
\hline
\end{tabular}

Forrás: Kérdöíves felmérés alapján saját szerkesztés

A tagok 57\%-a teljes mértékben úgy érzi, hogy a szövetkezet nemcsak anyai elönyöket biztosít számukra, hanem egy közösséghez való tartozást is jelent. Egy közösséget a közös célok, a megvalósításukat szolgáló közös cselekedetek és a bizalom tartja össze. Tehát a csoportkohézió kapesán fontos kitérnünk a későbbiekben a bizalom szerepére is.

A megkérdezett gazdák 69\%-a gondolja úgy, hogy büszkeséggel és elégedettséggel tölti el, hogy tagja lehet a szövetkezetnek, 20\%-a inkább egyet ért ezzel az állítással, míg csak a tagok 11\%-a számára közömbös. Ahhoz, hogy egy közösség egyben maradjon, épüljön, szükség van tagjai összefogásának és a közösségen belüli együttmüködésének magasabb szintre emelésére. A szövetkezeti tagok 66\%-ának állítása szerint teljes mértékben elkötelezett a tagok közötti összefogás és együttmüködés magasabb szintre emelésében, míg a tagok $26 \%$-a inkább elkötelezett, $8 \%$-a pedig közömbös e tekintetben.

A következőekben az ehhez köthető bizalom alakulását visgáltuk a tagok és a szövetkezet menedzsmentje között, valamint a tagok között.

8.5. A bizalom szerepe és mértéke a tagok és a menedzsment között

A közgazdaságtanban is elfogadott álláspont szerint a bizalom csökkenti a cserekapcsolatokban rejlő bizonytalanságot és kockázatot. A bizalom hiánya gátját képezheti a gazdasági hatékonyságnak és fejlödésnek (Dyer-Chu, 2003 idézi Biró et al., 2015; Kassai, 2012). A bizalom hatást gyakorol a csoportkohézióra, a tagok aktivitására, valamint az innováció elterjedésének sikerére. Alapvetően kétféle 
bizalmat különböztetünk meg: az érzelmi alapú (,affective”) és a racionális alapú (,cognitive”) bizalmat (Hansen et al., 2002).

\section{4. táblázat: A racionális és érzelmi alapú bizalom megítélése}

\begin{tabular}{|c|c|c|c|c|}
\hline \multicolumn{5}{|c|}{ Racionális alapú (,cognitive”) bizalom megítélése } \\
\hline \multicolumn{5}{|c|}{$\begin{array}{c}\text { Amikor azt értékelem, hogy megbízhatok-e egy másik szövetkezeti tagban, ugyanúgy } \\
\text { ésszerúen járok el, mint más üzleti partnerek esetében. }\end{array}$} \\
\hline $\begin{array}{c}\text { Egyáltalán nem } \\
\text { értek egyet }\end{array}$ & $\begin{array}{l}\text { Inkább nem } \\
\text { értek egyet }\end{array}$ & $\begin{array}{l}\text { Közömbös } \\
\text { számomra }\end{array}$ & $\begin{array}{l}\text { Inkább } \\
\text { egyetértek }\end{array}$ & $\begin{array}{l}\text { Teljes mértékben } \\
\text { egyetértek }\end{array}$ \\
\hline $6 \%$ & $\mathbf{3 \%}$ & $14 \%$ & $43 \%$ & $34 \%$ \\
\hline \multicolumn{5}{|c|}{$\begin{array}{l}\text { Amikor azt értékelem, hogy megbizhatok-e a szövetkezet vezetőiben, ugyanúgy ésszerúen } \\
\text { járok el, mint más üzleti partnerek esetében }\end{array}$} \\
\hline $\begin{array}{c}\text { Egyáltalán nem } \\
\text { értek egyet }\end{array}$ & $\begin{array}{l}\text { Inkább nem } \\
\text { értek egyet }\end{array}$ & $\begin{array}{l}\text { Közömbös } \\
\text { számomra }\end{array}$ & $\begin{array}{l}\text { Inkább } \\
\text { egyetértek }\end{array}$ & $\begin{array}{l}\text { Teljes mértékben } \\
\text { egyetértek }\end{array}$ \\
\hline $3 \%$ & $6 \%$ & $6 \%$ & $20 \%$ & $65 \%$ \\
\hline \multicolumn{5}{|c|}{ Érzelmi alapú („affective”) bizalom megítélése } \\
\hline \multicolumn{5}{|c|}{ Úgy érzem, hogy bízhatok a többi szövetkezeti tagban. } \\
\hline $\begin{array}{l}\text { Egyáltalán nem } \\
\text { értek egyet }\end{array}$ & $\begin{array}{l}\text { Inkább nem } \\
\text { értek egyet }\end{array}$ & $\begin{array}{l}\text { Közömbös } \\
\text { számomra }\end{array}$ & $\begin{array}{l}\text { Inkább } \\
\text { egyetértek }\end{array}$ & $\begin{array}{l}\text { Teljes mértékben } \\
\text { egyetértek }\end{array}$ \\
\hline $0 \%$ & $6 \%$ & $11 \%$ & $49 \%$ & $34 \%$ \\
\hline \multicolumn{5}{|c|}{ Úgy érzem, hogy bízhatok a szövetkezet vezetôiben. } \\
\hline $\begin{array}{l}\text { Egyáltalán nem } \\
\text { értek egyet }\end{array}$ & $\begin{array}{l}\text { Inkább nem } \\
\text { értek egyet }\end{array}$ & $\begin{array}{l}\text { Közömbös } \\
\text { számomra }\end{array}$ & $\begin{array}{c}\text { Inkább } \\
\text { egyetértek }\end{array}$ & $\begin{array}{l}\text { Teljes mértékben } \\
\text { egyetértek }\end{array}$ \\
\hline $\mathbf{0 \%}$ & $0 \%$ & $3 \%$ & $\mathbf{2 8 \%}$ & $69 \%$ \\
\hline
\end{tabular}

Forrás: Kérdöíves felmérés alapján saját szerkesztés

A 4. táblázat alapján elmondható, hogy a racionális alapú bizalom vonatkozásában a megkérdezettek, inkább bizalmatlanok egymással szemben, illetve a szövetkezet vezetőivel kapcsolatosan, miközben az érzelmi alapú bizalom esetében ez éppen a fordítottja, azaz a tagok nagy arányban éreznek bizalmat érzelmi alapon a többi tag és a vezetőség iránt. Mindez nagymértékben befolyásolhatja a tagok elköteleződését a szövetkezet irányában.

Továbbá a bizalomnak nagyon fontos szerepe van a szövetkezeten belüli kapcsolatok minőségének, mennyiségének és intenzitásának meghatározásában, mely kapcsolatok a tagok között gazdasági, szakmai és személyes vonatkozásúak. A szövetkezet vezetősége igyekszik összekapcsolni, összehozni azokat a tagokat, akik felesleges áruikat tudják egymás között értékesíteni. Szakmai kapcsolat a tagok között a tapasztalatcsere, melyre például a fogadóórák kereti között van lehetőség, valamint a közös szakmai kirándulások, amelyek során más telepekre látogatva tanulmányozhatják például a tartástechnológiát. Személyes kapcsolat alakulhat ki a tagok között a Családi nap, a közös kirándulások vagy a fogadóórák alkalmával.

A szövetkezet vezetősége és a tagok között szakmai és gazdasági kapcsolatról beszélhetünk. A szövetkezet bonyolítja le a tranzakciókat, másrészröl viszont vagy 
személyesen, vagy telefonon, de igyekszik az elnök minden taggal folyamatos kapcsolatot tartani, megbeszélve a szakmai tapasztalatokat.

\subsection{Az innováció szerepe}

Az innováció szerepét és jelentőségét nem hagyhatjuk figyelmen kívül, hiszen tudjuk, hogy ma milyen fontos szerepet játszik a társadalmi és gazdasági fejlődésben. Ahhoz, hogy az adott vállalkozás eredményesen helyt tudjon állni a piaci versenyben, szükség van a folyamatos megújulásra és az újdonságok keresésre. Az innováció ma már egyfajta kényszerré vált a vállalkozások számára, hiszen nemcsak a versenyképesség és a piaci trendek követése miatt fontos, hanem a vállalkozások létét is jelentik. Ugyanakkor nagy kihívást is jelent a társadalmak és gazdaságok számára. A tudás megosztása, a kreativitás, a csapatmunka, a bizalom vagy az alkalmazott szakemberek azok, amely biztosíthatják az innováció jelenlétét. A vállalkozási hajlandósággal, a folyamatos innovációval adott esteben nem kockáztatnak a vezetők, hanem éppen ellenkezőleg, képesek kezelni a bizonytalanságot és a kockázatos helyzeteket (Benkő-Kiss et al., 2010; MatrasBolibok-Kis, 2014; Nagy, 2014; Szabó, 2012).

A szövetkezeti tagokat a kérdöíves felmérés során az innovációval kapcsolatos információforrások fontosságáról kérdeztük, valamint arról, hogy mennyire ösztönözi őket a szövetkezet innovációra. A TAR-TÓ 2000 Szövetkezet bizonyult a legfontosabb információforrásnak, hiszen a tagok $80 \%$-a gondolja úgy, hogy nélkülözhetetlen, a $20 \%$-a pedig, hogy nagyon fontos. A szövetkezet mellett kiemelkedő információforrás a tagok 34\%-a szerint a vevők és ügyfelek, valamint az input beszállítók.

A megkérdezett szövetkezeti tagok 29\%-a gondolja úgy, hogy teljes mértékben, 51\%-a szerint nagymértékben, $17 \%$-a közepesen, míg $6 \%$ szerint csak kismértékben ösztönözi a TAR-TÓ 2000 Szövetkezet innovációra. A szövetkezetben megszerzett információk, a szövetkezet vezetősége által kipróbált új eljárások és technológiák azok, amelyek a leginkább hatnak a tagok új felé való elmozdulásban. Ahhoz, hogy a tagok adaptálják gazdaságukba a szövetkezet által kipróbált eljárásokat bizalomra van szükség. Tehát megállapíthatjuk, hogy a Szövetkezet nagy hatással van a gazdákra az innováció terén, számukra az egyik legfontosabb információforrás, mely nagymértékben hozzájárul ahhoz, hogy kipróbáljanak valami újat, fejlesszenek és beruházzanak.

\subsection{A TAR-TÓ 2000 Szövetkezet szerepe a humanisztikus célok elérésében}

A szövetkezetek gazdasági céljai mellett megjelennek a méltányossági célok is, melyek a tagok jóllétéhez igyekeznek hozzájárulni. A szövetkezetek müködésének egyes jellemzői, mint a csoportkohézió, a bizalom mértéke, az innováció szerepe keretet biztosítanak, elősegítik a tagok társadalmi és kulturális célok iránti törekvését, nem csak az anyagi hozzájárulás által.

A TAR-TÓ 2000 Szövetkezet igyekszik szerepet játszani a humanisztikus célok elérésében is, hiszen az anyagi haszon mellett, megpróbálja a tagokat közelebb hozni egymáshoz, például a minden évben megrendezett családi nap által, az évi rendes 
közgyülést követően, ahol a gazdák nem csak a gyülésen elhangzottakat értékelhetik és beszélhetik meg egymás között, de lehetőségük nyílik az ismerkedésre, barátságok kialakítására is.

A szövetkezet elnöke időközönként tanulmányi kirándulást is szervez a tagok számára, lehetőség és igény szerint, ami során meglátogatnak más telepeket, tanulmányozva az ott lévő tartástechnológiát és körülményeket, ezzel is elősegítve a gazdálkodókat az innovációra való törekvésben, valamint a szövetkezeti tagok egymáshoz való közelebb hozásában.

A tanulmányutak mellett, szerveztek már csapatépítő kirándulást is, melynek célja a kikapcsolódás és szintén a tagok egymáshoz való közelebb kerülése, egymás megismerése.

A szövetkezetben minden héten, kedden és pénteken a fogadóóra keretei között a gazdáknak lehetősége nyílik a személyes ügyintézésre. A kérdöíves felmérés során, a fogadóórára járás céljaként a gazdálkodók megemlítették, hogy az ügyintézés mellett beszélgetni járnak a gazdatársaikkal, valamint fontos a családias hangulat is. A személyes tapasztalat is az volt, hogy sokan nem csak az ügyintézés miatt jönnek, hanem egy találkozó helyként is funkcionál a szövetkezet, ahol a gazdák kisebb csoportokba elvonulva megbeszélik az aktualitásokat, mind a gazdasági mind a magán életi oldalról.

\section{9. Összefoglalás}

Ma a magyar mezőgazdaságnak számos kihívással és problémával kell szembenéznie. Ahhoz, hogy felvegye a versenyt a nyugati országokkal, szemléletváltásra lenne szükség a gazdálkodók körében. Az együttmüködések, szövetkezések által olyan elönyökhöz juthatnának a gazdák, amit máshol nem vagy csak nehezen tudnának megszerezni.

A szövetkezetek nem csak a gazdasági jólétet növelik, de hozzájárulnak a humanisztikus célok eléréhez, hozzásegítve az embereket a fenntarthatóság eléréhez, és a társadalmi különbségek csökkentéséhez.

$\mathrm{Az}$ általunk vizsgált TAR-TÓ 2000 Szövetkezetnek kezdetben egyetlen célja volt, a közös értékesítés. Később felmerült a közös beszerzés gondolata is. A szövetkezet menedzsmentje cserélödött, a tagok létszáma évröl, évre folyamatosan növekedett, beruházások indultak el, a szolgáltatások skálája bővült, majd idővel megjelentek a humanisztikus célok is. A szövetkezet igyekszik a hatékonyság növelésére és emellett egy összetartó közösség kialakítására.

A szövetkezetek egyes jellemzői, mint a csoportkohézió, bizalom szerepe, innováció mind hozzájárulnak a méltányossági célok felé való elmozdulásban. A felmérésböl kiderült, hogy a szövetkezet fontos szerepet játszik a tagok innovációra való ösztönzésében, a tájékoztatásban, információ és tudásáramlásban. Továbbá megállapíthatjuk, hogy tagok inkább bíznak a szövetkezet vezetöségében, mint egymásban. Nem csak anyagi elönyöket nyújt a szövetkezet a tagok számára, hanem egy közösség részévé igyekszik tenni a gazdákat. 


\section{Irodalomjegyzék}

Benkő-Kiss Á., Bodnár K., Kis K., Horváth J. (2010): Agrárvállalkozások innovációérzékenysége a Dél-alföldi Régióban. Kutatási jelentés: BAROSS DA_ELEM_07_ MGK_INNO. Szegedi Tudományegyetem Mezőgazdasági Kar, Hódmezővásárhely.

Biró Sz., Rácz K., Csörnyei Z., Hamza E., Varga E., Bene E., Miskó K. (2015): Agrár- és vidékfejlesztési együttmüködések Magyarországon. Agrárgazdasági Kutató Intézet, Budapest.

Chikán A. (1992): Vállalatgazdaságtan. AULA Kiadó, Budapest.

Dorgai L., Hamza E., Miskó K., Székely E., Tóth E.(2005): Termelöi szervezódések, termelöi csoportok a mezögazdaságban. Agrárgazdasági Kutató Intézet, Budapest.

FAO: Food and Agriculture Organization of the United Nations (2012a): Mezőgazdasági szövetkezetek: kulcs a világ élelmezéséhez. Élelmezési Világnap 2012. október 16. $<$ http://www.fao.org/fileadmin/user_upload/Europe/documents/wfd2012/REU_szorolap_hu.pd f>. (2017.01.22.)

FAO: Food and Agriculture Organization of the United Nations (2012b): Agricultural cooperatives: key to feeding the world. FAO, Rome. $<$ http://www.fao.org/fileadmin/templates/getinvolved/images/WFD2012_leaflet_en_low.pdf $>$. (2017.02.28.)

Fogarassy Cs., Villányi L. (2004): Agrárgazdaságtan I. Szent István Egyetem, Gödöllö.

Hansen, M. H., Morrow, J. L. Jr., Batista, J. C. (2002): The impact of trust on cooperative membership retention, performance, and satisfaction: an exploratory study. International Food and Agribusiness Management Review, 2002 (5): 41-59.

Hunyadi A. (2007): A különbözö szövetkezeti típusok és a szövetkezeti értékrend kialakítása.In: Somai J. (szerk.): Szövetkezetek Erdélyben és Európában. Romániai Magyar Közgazdász Társaság, Kolozsvár. 111-140.

ICA: International Co-operative Alliance (é.n.): History of the co-operative movement. $<$ http://ica.coop/en/whats-co-op/history-co-operative-movement> (2017.04.20.)

Kassai Zs. (2012): Együttmüködés a vidék fenntartható fejlesztéséért. In: A mezógazdaságtól a vidékgazda(g)ságig. LIV. Georgikon Napok. (2012.10.11-2012.10.12.) Pannon Egyetem Georgikon Kar, Keszthely. <http://napok.georgikon.hu/cikkadatbazis/cikkek2012/doc_view/12-kassai-zsuzsanna-egyuttmukodes-a-videk-fenntarthato-fejleszteseert>. 268275.

Kis K., Kovács H., Szatmári G., Tóth M. (2016): A szociális szövetkezetek szerepe a vidékfejlesztésben - Esettanulmány: A Bergendóc Szociális Szövetkezet müködésének és eredményeinek értékelése. Jelenkori társadalmi és gazdasági folyamatok, 9 (1-2): 9-34.

Kispál-Vitai Zs. (2006): Gondolatok a szövetkezéselmélet fejlödéséröl. Közgazdasági szemle, 53 (1): 69-84.

Kispál-Vitai Zs. (2013): A szövetkezet átalakulása befektetöi tulajdonú társasággá - elkerülhetetlen jövö? Gazdálkodás, 57 (3): 260-269.

Lukács E. (2005): A vállalatelméletek meghatározó csoportja - A magatartási elméletek. Gazdaságtudományi Közlemények, 4 (1): 35-49.

Matras-Bolibok, A., Kis, K. (2014): European Innovation Partnership as a Framework for Open Innovation in Agriculture. Annals of the Polish Association of Agricultural and Agribusiness Economists, 16 (6). 339-343.

Nagy S. (2014): Stratégiai esettanulmányok. In: Gulyás L. (szerk.): Stratégiai menedzsment Szun-Cetól a kék óceánig. JATEPress, Szeged. 137-188.

Oláh J., Balogh P., Lakner Z., Popp J. (2016): Az alapanyagkészlet csökkentését szolgáló folyamatok bemutatása az ellátási láncban. Információs Társadalom, 16 (4): 61-84. DOI: http://dx.doi.org/10.22503/inftars.XVI.2016.4.4

Ortmann G. F., King, R. P. (2007): Agricultural Cooperatives I: History, theory and problems. Agrekon, 46 (1): 40-68. 
Petheö A. I., Györi Zs., Németh B., Fekete N., Simon F. (2010): A szociális szövetkezetek múködési modelljének kidolgozása a foglalkoztatás elősegítése érdekében. Budapesti Vállalkozásfejlesztési Kutató Intézet, Budapest.

Puusa, A., Mönkkönen, K., Varis, A. (2013): Mission lost? Dilemmatic dual nature of co-operatives. Journal of Co-operative Organization and Management, 1 (1): 6-14.

Simon S. (1999): A szövetkezeti törekvések múltja és jelene. Magyar Kisebbség, 5 (1): <http://magyarkisebbseg.ro/index.php?action=cimek\&lapid=11\&cikk=m990120.htm> (2017.04.20.)

Szabó G. G- (2013): Gondolatok az élelmiszer-gazdasági szövetkezés gazdasági lényegéröl és integrációs jelentőségéről. Gazdálkodás, 57 (3): 203-223.

Szabó Zs. R. (2012): Adaptáció és a növekedés lehetőségei és korlátai a kkv-szektorban. In: Szabó Zs. R. (szerk.): Innováció vezetői szemmel. AULA Kiadó, Budapest. 35-54.

SZÖVKUT: Szövetkezeti Kutató Intézet (é.n.): Szövetkezeti identitás. <http://www.szovetkezetikutato.hu/szovetkezeti_identitas.php> (2017.04.18.)

Villányi L., Vasa L. (2008): Agrárgazdaságtan. Szaktudás Kiadó Ház, Budapest.

Viszket Z. (2013): A magyar szövetkezeti mozgalom múltja - források a "futura" történetéból. $<$ http://www.archivnet.hu/gazdasag/a_magyar_szovetkezeti_mozgalom_multja_forrasok_a_f utura_tortenetebol.html> (2017.04.21.)

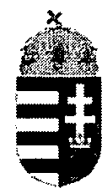

\section{AZ EMBERI ERŐFORRÁSOK MINISZTÉRIUMA \\ Új Nemzeti Kiválóság Programjának TÁMOGATÁSÁVAL KÉSZÜLT.}

EMBERI ERÖFORRÁSOK

MINISZTÉRIUMA 